DOI: $10.38136 / j g o n .760413$

\title{
Düşük Riskli Bir Gebe Populasyonunda Gebelik Haftasına Göre İri Fetusların Tahmin Edilmesi Amacıyla Gestasyonel Kilo Alımı İçin Bir Eşik Değer
}

\section{A Cut-off Value for Gestational Weight Gain to Predict Large for Gestational Age Fetuses in a Low-risk Pregnant Population}

\author{
Saime YETiȘ \\ Atakan TANACAN \\ Esra KARATAȘ ${ }^{2}$ \\ Namık DEMIR \\ Mehmet Sinan BEKSAC \\ (1) Orcid ID:0000-0002-8849-1478 \\ (1) Orcid ID:0000-0001-8209-8248 \\ (1) Orcid ID:0000-0003-3474-2398 \\ (1) Orcid ID:0000-0003-1708-7870 \\ (1) Orcid ID:0000-0001-6362-787X \\ ${ }^{1}$ Private Clinic, Izmir. Turkey \\ ${ }^{2}$ Division of Perinatology, Department of Obstetrics and Gynecology, Hacettepe University, Ankara,Turkey \\ ${ }^{3}$ Kent Hospital, Izmir, Turkey
}

\section{Öz}

Amaç: Doğum haftasına göre iri bebekleri (LGA) tahmin etmek amacıyla gestasyonel kilo alımı için bir eşik değer belirlemek.

Gereç ve Yöntemler: Bu retrospektif kohort çalışması, 1 Ocak 2018 ile 31 Aralık 2018 tarihleri arasında İzmir'deki bir özel hastaneye başvuran 103 hamile kadın üzerinde gerçekleştirildi. Hastalar neonatal doğum ağırığı persantilleri açısından iki gruba ayrıldı: 1) LGA grubu ( $\geq 90$ persentil)(n=11) ve 2) LGA olmayan grup (n=92). Demografik özellikler ve klinik karakteristikler gruplar arasında karşılaştırıldı. Ayrıca, LGA fetüslerinin tahmini amacıyla hamilelik sırasında maternal kilo alımı için bir eşik değeri belirlendi.

Bulgular: LGA grubunda diğer gruba göre belirgin olarak daha yüksek gestasyonel kilo alımı ve sezaryen oranı gözlendi ( $p$ değerleri sırasıyla 0.01 ve 0.03 ). LGA bebekleri tahmin etmek amacıyla gestasyonel kilo alımı için eşik değer olarak $16.1 \mathrm{~kg}$ belirlendi (\% 72.7 duyarııık,\% 60.9 özgüllük).

Sonuç: Hamilelik sırasında aşırı kilo alımı konusunda dikkatli olunmaIıdır.

Anahtar kelimeler: doğum kilosu, gestasyonel kilo alımı, doğum haftasına göre iri bebek, gebelik.

\section{INTRODUCTION}

Weight gain within an appropriate range is a physiological part of pregnancy (1). Developing fetus, maternal fat stores, increased extravascular/intravascular fluid volume, amniotic fluid, breast enlargement, uterine hypertrophy and placenta all contribute to total weight gain during pregnancy (2-4). However, both inadaquate and excessive gestational weight gain may cause various perinatal complications (2-4). Risk of gestational diabetes mellitus (GDM), preeclampsia and cesarean section (CS) are increased in pregnant women with excessive gestational weight gain. On the other hand, pregnant women with inadaquate gestational weight gain are at increased risk for delivery of

\section{ABSTRACT}

Objective: To determine a cut-off value for gestational weight gain for the prediction of large for gestational age (LGA) fetuses

Materials and Methods: This retrospective cohort study was conducted among 103 pregnant women who delivered at a private hospital in Izmir between January, 1, 2018 and December, 31, 2018. Patients were divided into two groups in terms of neonatal birth weight percentiles: 1) LGA group ( $\geq 90$ percentile) ( $n=11), 2)$ Non-LGA Group ( $n=92)$. Demographic features and clinical characteristics were compared between the groups. Additionally, a cut-off value for maternal weight gain during pregnancy was determined for the prediction of LGA fetuses.

Results: Significantly higher total weight gain during pregnancy and higher cesarean rates were observed in LGA group compared to non-LGA group ( $p$ values were 0.01 and 0.03 , respectively). The cut-off value of $16.1 \mathrm{~kg}$ for gestational weight gain $(72.7 \%$ sensitivity, $60.9 \%$ specificity) was determined for the prediction of LGA fetuses.

Conclusion: Physicians should be cautious about excess weight gain during pregnancy.

Key words: birth weight, gestational weight gain, large for gestational age, pregnancy.

a small for gestational age (SGA) neonate and preterm labor (2-4). Thus, appropriate regulation of gestational weight gain has become an integral part of antenatal care programs in the last decades (5).The relationship between excessive gestational weight gain and increased birth weight values were reported in many studies $(4,6-10)$. As increased birth weight is associated with increased rates of various obstetric/neonatal complications like genital tract lacerations, postpartum hemorrhage, uterine rupture, shoulder dystocia and neonatal intensive care unit admissions, preventing excessive gestational weight gain was recommended in order to obtain favorable obstetric outco- 
mes (4, 6-10). However, there are ongoing debates about the upper limit of gestational weight gain values which increases the risk of adverse pregnancy outcomes (11).

The aim of this study is to determine a cut-off value for maternal weight gain during pregnancy at a low risk pregnant population for the prediction of LGA fetuses.

\section{MATERIALS AND METHOD}

This retrospective cohort study was conducted among 103 pregnant women who delivered at a private hospital in Izmir between January, 1, 2018 and December, 31, 2018. The required data were extracted from the database of a private physician's office. Pregnant women who had normal body mass index (BMI) values before pregnancy (18.5-24.9 kg/m2) and who delivered singleton alive babies at term (after 37 th gestational week) were included in the study. Pregnancies with fetal growth restriction, chromosomal/structural abnormality, preeclampsia, preterm premature rupture of the membranes and/or with maternal diseases like type 1 diabetes mellitus, systemic lupus erythematosus, chronic hypertension and chronic renal failure were excluded from the study. Eligible patients were divided into two groups in terms of neonatal birth weight percentiles: 1) Large for gestational age (LGA) group ( $n=11), 2$ ) Non-LGA Group ( $n=92$ ). Maternal age, gravidity, parity, BMl (at 3 months before pregnancy, 14th gestational week, 28th gestational week, delivery and postpartum 6 th week), total weight gain during pregnancy, fasting blood glucose at first trimester, $50 \mathrm{~g}$ glucose challenge (GCT) test value, gestational diabetes mellitus (GDM) rate, gestational week at birth, 5th minute APGAR scores and cesarean (CS) rates were compared between the groups. Additionally, a cutoff value of maternal weight gain during pregnancy for the prediction of LGA fetuses were determined.

Large for gestational age was defined as birth weight $\geq 90$ th percentile for gestational age (12). Routine antenatal care program was applied to all pregnant women. Pregnancy follow-up consisted of serial ultrasonography to evaluate fetal growth, aneuploidy screening (combined or triple test), fetal anatomy scanning at the 18th-22th gestational weeks, $50 \mathrm{~g} \mathrm{GCT}$ at the 24th-28th gestational weeks, and non-stress in the last weeks of gestation. Diagnosis of GDM was made according to the American Diabetes Association criteria (13).

Statistical analyses were performed using the Statistical Package for the Social Sciences (SPSS.22, IBM SPSS Statistics for Windows, Version 22.0 Armonk, NY: IBM Corp.). The variables were investigated using visual (histograms, probability plots) and analytical methods (Shapiro-Wilk's test) to determine whether they were normally distributed. Descriptive analyses were presented as medians and interquartile range for the non-normally distributed variables. As continuous variables were not normally distributed, the Mann-Whitney $\mathrm{U}$ test was conducted to compare the median values among the groups. Categorical variables were defined based on numbers and percentages. The Chi-square test was used to compare categorical variables among the groups. Receiver operating characteristic (ROC) curves was used to assess the performance of maternal weight gain during pregnancy in predicting LGA. Youden index was applied to ROC curve to choose the best cut-off values (14). A two-tailed $P$ value $<0.05$ was regarded as statistically significant.

Informed consents were obtained from all participants. Retrospective study protocol was approved by Izmir Economy University (B.30.2. İEÜSB.0.05.05-20-049).

\section{RESULTS}

Demographic features and clinical characteristics of the study patients were shown in Table 1.

Table 1: Demographic features and clinical characteristics of the study patients

\begin{tabular}{|c|c|c|c|}
\hline Variables & Non-LGA group $(\mathrm{n}=92)$ & LGA group (n=11) & $p$ values \\
\hline $\begin{array}{l}\text { Maternal age (years) } \\
(\text { (median, IQR) }\end{array}$ & $26.5(5)$ & $26(5)$ & 0.54 \\
\hline Gravidity (median, IQR) & $1(1)$ & $1(2)$ & 0.52 \\
\hline Parity $(\text { median, IQR) })^{2}$ & $0(1)$ & $0(1)$ & 0.96 \\
\hline $\begin{array}{l}\text { BMI at } 3 \text { months before } \\
\text { pregnancy }\left(\mathrm{kg} / \mathrm{m}^{2}\right)(\mathrm{me}- \\
\text { dian, IQR) }\end{array}$ & $22.5(3.5)$ & $23.2(4.2)$ & 0.32 \\
\hline \begin{tabular}{|l|} 
BMI at $14^{\text {th }}$ gestational \\
week $\left(\mathrm{kg} / \mathrm{m}^{2}\right)($ median, \\
IQR) $^{\mathrm{a}}$
\end{tabular} & $22.7(3.4)$ & $23.7(4.6)$ & 0.29 \\
\hline $\begin{array}{l}\text { BMI at } 28^{\text {th }} \text { gestational } \\
\text { week }\left(\mathrm{kg} / \mathrm{m}^{2}\right)(\text { median, } \\
\mathrm{IQR})^{\mathrm{a}}\end{array}$ & $26.3(4)$ & $27.4(2.7)$ & 0.20 \\
\hline $\begin{array}{l}\text { BMI at delivery }\left(\mathrm{kg} / \mathrm{m}^{2}\right) \\
\text { (median, IQR) }\end{array}$ & $28.7(4.7)$ & $29.3(3.3)$ & 0.18 \\
\hline $\begin{array}{l}\text { BMI at postpartum } 6^{\text {th }} \\
\text { week }\left(\mathrm{kg} / \mathrm{m}^{2}\right)(\text { median, } \\
\text { IQR) }\end{array}$ & $25.9(4.2)$ & $26.1(3.9)$ & 0.61 \\
\hline $\begin{array}{l}\text { Total weight gain during } \\
\text { pregnancy (kg) (medi- } \\
\text { an, IQR) } \\
\end{array}$ & $15(6)$ & $18.3(5)$ & 0.01 \\
\hline \begin{tabular}{|l|} 
Fasting blood glucose at \\
first trimester (mg/dl) \\
(median, IQR) $^{\mathrm{a}}$ \\
\end{tabular} & $80(9)$ & $83(12)$ & 0.07 \\
\hline $\begin{array}{l}\begin{array}{l}50 \mathrm{~g} \mathrm{GCT} \text { value }(\mathrm{mg} / \mathrm{dl}) \\
(\text { (median, IQR) }\end{array} \\
\end{array}$ & $121(35)$ & $129(46)$ & 0.13 \\
\hline GDM rate $(\mathrm{n}, \%)^{\mathrm{b}}$ & $23(25 \%)$ & $4(36.3 \%)$ & 0.42 \\
\hline $\begin{array}{l}\text { Gestational week at } \\
\text { birth (median, IQR) }\end{array}$ & $39(1)$ & $39(1)$ & 0.46 \\
\hline $\begin{array}{l}5^{\text {th }} \text { minute APGAR Score } \\
\text { (median, IQR) }\end{array}$ & $10(1)$ & $9(1)$ & 0.09 \\
\hline CS rate $(\mathrm{n}, \%)^{\mathrm{b}}$ & $44(47.8 \%)$ & $9(81.8 \%)$ & 0.03 \\
\hline
\end{tabular}

LGA: Large for gestational age, IQR: Inter-quartile range, BMI: Body-mass index, GCT: Glucose challenge test, GDM: Gestational diabetes mellitus, CS: Cesarean section

a Statistical analysis was performed by Mann-Whitney $U$ test

b Statistical analysis was performed by Chi-square test

Non-LGA and LGA groups were comparable in terms of maternal age, gravidity, parity, BMl (at 3 months before pregnancy, 14th gestational week, 28th gestational week, delivery and postpartum 6th week), fasting blood glucose at first trimester, $50 \mathrm{~g}$ GCT value, GDM rate, gestational week at birth and 5th minute APGAR score ( $p$ values were 0.54, 0.52, 0.96, 0.32, 0.29, 0.20, 0.18, $0.61,0.07,0.13,0.42,0.46$ and 0.09 , respectively). On the other hand, significantly higher total weight gain during pregnancy and hgher CS rate values were observed in LGA group compared to non-LGA group ( $p$ values were 0.01 and 0.03 , respectively). No birth trauma or postpartum hemorrhage was observed in any of the cases and none of the newborns were transferred to neonatal intensive care unit.

Receiver operating characteristic curve analysis for assessing the the performance of weight gain during pregnancy in predicting LGA was shown in Figure 1 and Table 2. Area under the curve (AUC) was calculated as 0.724 (95\% Cl: 0.59-0.85) for LGA. The values in ROC curves with the best balance of sensitivity/specificity was, $16.1 \mathrm{~kg}(72.7 \%$ sensitivity, $60.9 \%$ specificity) for LGA according to the results obtained from the Youden index. 
Figure 1. Receiver operating characteristic (ROC) curve analysis for assessing the the performance of weight gain during pregnancy in predicting large for gestational age (LGA).

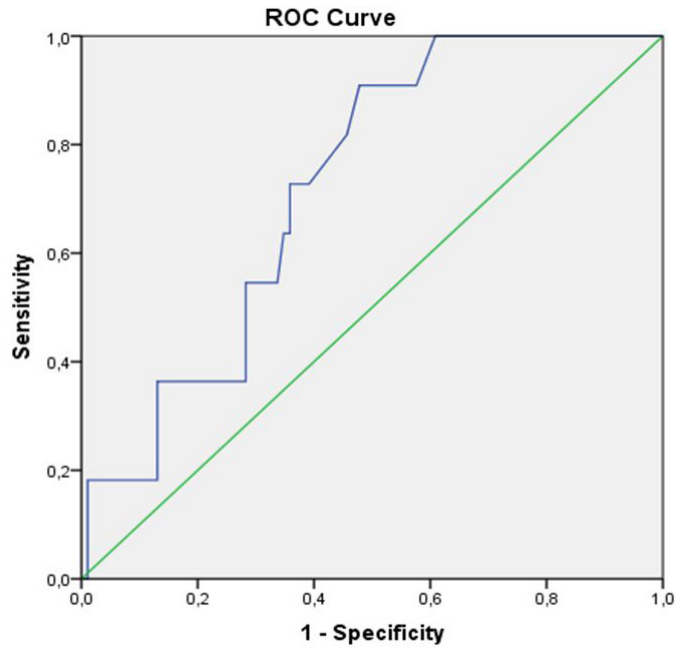

Diagonal segments are produced by ties.

Table 2: Receiver operating characteristic (ROC) curve analysis for assessing the the performance of weight gain during pregnancy in predicting LGA.

\begin{tabular}{|l|l|l|l|l|}
\hline $\begin{array}{l}\text { LGA } \\
\text { (AUC: } 0.724,95 \% \\
\text { Cl: } 0.59-0.85)\end{array}$ & $\begin{array}{l}\text { Cut-off value for } \\
\text { maternal weight } \\
\text { gain during preg- } \\
\text { nancy (kg) }\end{array}$ & Sensitivity & Specifity & $p$ value \\
\hline & 16.1 & $72.7 \%$ & $60.9 \%$ & 0.015 \\
\hline
\end{tabular}

\section{DISCUSSION}

The effect of pre-pregnancy weight and gestational weight gain on obstetric outcomes has long been known (2-4). Especially, excessive weight gain is a major concern for physicians as it is associated with increased risk of GDM, preeclampsia and macrosomia (2-4). However, no consensus has been reached on the upper limit of gestational weight gain for the time being $(11,15)$. First comprehensive recomendations for healthy gestational weight gain was published in 1990 by Institute of Medicine (IOM) (16). These recommendations mostly focused on pre-pregnancy BMI and they have some limitations related to characteristics of the data used. Thus, IOM revised their 1990 guidelines in 2009 according to the current literature (15). Topics about twin pregnancies and obese women were included to this updated version (15). Nevertheless, 2009 guidelines had still limitations related to some adverse pregnancy outcomes like preeclampsia and GDM. Additionally, obesity classes were not seperately evaluated (15). For this reason, a more comprehensive meta-analysis was published in 2019 by the "LifeCycle Project-Maternal Obesity and Childhood Outcomes Study Group" (11). High quality, pooled data of individual patients from many countries were used in this current meta-analysis (11). The main finding of this study was that pre-pregnancy BMI was more strongly associated with adverse pregnancy outcomes than gestational weight gain (11). On the other hand, a low or moderate relationship was found between adverse pregnancy outcomes and gestational weight gain (11). Therefore, our knowledge on optimal gestational weight gain in pregnant women with normal pre-pregnancy BMl values is still questionable.

A homogenous singleton pregnant population with normal pre-pregnancy $\mathrm{BMI}$ values and with low risk factors for LGA fetuses were evaluated in this study. As the number of patients is relatively small, we mainly focus on the impact of gestational weight gain on LGA fetuses. Higher gestational weight gain values were observed in the pregnant women with LGA fetuses. Our findings were consistent with the current literature. Higher risk for LGA was also observed in a study of 4321 cases (OR 2.86; 95\% Cl 2.09-3.92) (4) Similarly, higher risk of LGA (OR 1.85, 95\% Cl 1.76-1.95) and macrosomia (OR 1.95, $95 \% \mathrm{Cl} 1.79-2.11)$ was reported in a 2017 systematic review of 23 studies ( $n=1309136$ women) (6). Moreover, a 2014 meta-analysis of 15 studies indicated increased risk of macrosomia for excessive gestational weight gain (OR 2.35 95\% Cl 1.95-2.85) (9). A 11.5 to $16 \mathrm{~kg}$ weight gain was recommended for pregnant women with normal pre-pregnancy BMI values in IOM 2009 guidelines (15). Additionally, lower rates of adverse pregnancy outcomes were reported for pregnant women with normal pre-gestational BMI values with gestational weight gain of 10 to $18 \mathrm{~kg}$ in the "LifeCycle Project-Maternal Obesity and Childhood Outcomes Study Group's" metaanalysis. Both the median gestational weight gain in LGA group and the cut-off value for LGA prediction were higher than the determined values in this study $(11,15)$.

Higher rates of impaired glucose metabolism during pregnancy and CS rates were reported in the literature for pregnant women with excessive gestational weight gain $(2-4,17,18)$. Similar rates for GDM were observed for both groups in this study which was different from the literature. This finding was most probably due to the lower frequencies of risk factors for GDM in the study population and relatively small number of the patients. On the other hand, increased rates of CS was observed in the LGA group which was consistent with the literature $(2-4,17,18)$. Moreover, LGA was found to be associated with increased rates of birth trauma, postpartum hamorrhage and various neonatal complications $(4,6-10,19)$. However, fortunately neither labor related complications nor neonatal comorbidities were observed in our study population. These findings may be related to small number of cases and close follow-up of the pregnancies.

\section{Strengths and Limitations}

The main strenghts of this study were relatively high number of variables and the presence of standardized protocols for all patients. Additionaly, we believe that retrieval of data from a "Private Physicians Office" is a great advantage in routine daily practice and indicative reference for general obstetricians. However, the main limitations were retrospective design and small number of patients. The other disadvantage is the inclusion of only low-risk pregnant population.

\section{CONCLUSION}

In conclusion, excessive gestational weight gain even in the low risk pregnant women seems to be associated with LGA. Physicians should be cautious about excess gestational weight gain especially when it exceeds $16.1 \mathrm{~kg}$.

\section{REFERENCES}

1. Alavi N, Haley S, Chow K, McDonald SD. Comparison of national gestational weight gain guidelines and energy intake recommendations. Obesity reviews : an official journal of the International Association for the Study of Obesity. 2013;14(1):68-85.

2. Chung JG, Taylor RS, Thompson JM, Anderson NH, Dekker GA, Kenny LC, et al. Gestational weight gain and adverse pregnancy outcomes in a nulliparous cohort. European journal of obstetrics, gynecology, and reproductive biology. 2013;167(2):149-53.

3. Daemers DO, Wijnen HA, van Limbeek EB, Bude LM, de Vries RG. Patterns of gestational weight gain in healthy, low-risk pregnant women without co-morbidities. Midwifery. 2013;29(5):535-41.

4. Ferraro ZM, Barrowman N, Prud'homme D, Walker M, Wen SW, Rodger M, et al. Excessive gestational weight gain predicts large for gestational age neonates independent of maternal body mass index. The journal of maternal-fetal \& neonatal medicine : the official journal of the European As- 
sociation of Perinatal Medicine, the Federation of Asia and Oceania Perinatal Societies, the International Society of Perinatal Obstet. 2012;25(5):538-42.

5. Kominiarek MA, Peaceman AM. Gestational weight gain. American journal of obstetrics and gynecology. 2017;217(6):642-51.

6. Goldstein RF, Abell SK, Ranasinha S, Misso M, Boyle JA, Black MH, et al. Association of Gestational Weight Gain With Maternal and Infant Outcomes: A Systematic Review and Meta-analysis. Jama. 2017;317(21):2207-25.

7. Stotland NE, Hopkins LM, Caughey AB. Gestational weight gain, macrosomia, and risk of cesarean birth in nondiabetic nulliparas. Obstetrics \& Gynecology. 2004;104(4):671-7.

8. Dietz PM, Callaghan WM, Sharma AJ. High pregnancy weight gain and risk of excessive fetal growth. American journal of obstetrics and gynecology. 2009;201(1):51. e1-. e6.

9. Tian C, Hu C, He X, Zhu M, Qin F, Liu Y, et al. Excessive weight gain during pregnancy and risk of macrosomia: a meta-analysis. Archives of gynecology and obstetrics. 2016;293(1):29-35.

10. Seçkin B, Özakşit G, Biteker G, Yüksel K, Ayarcan E. Maternal Body Mass Index and the course of the labor. Gynecology Obstetrics \& Reproductive Medicine. 2011;17(1):12-5.

11. Voerman E, Santos S, Inskip H, Amiano P, Barros H, Charles MA, et al. Association of Gestational Weight Gain With Adverse Maternal and Infant Outcomes. Jama. 2019;321(17):1702-15.

12. Duryea EL, Hawkins JS, McIntire DD, Casey BM, Leveno KJ. A revised birth weight reference for the United States. Obstetrics and gynecology. 2014;124(1):16-22.
13. 2. Classification and Diagnosis of Diabetes: Standards of Medical Care in Diabetes-2019. Diabetes care. 2019;42(Suppl 1):S13-s28.

14. Fluss R, Faraggi D, Reiser B. Estimation of the Youden Index and its associated cutoff point. Biometrical Journal: Journal of Mathematical Methods in Biosciences. 2005;47(4):458-72.

15. Gilmore LA, Redman LM. Weight gain in pregnancy and application of the 2009 IOM guidelines: toward a uniform approach. Obesity. 2015;23(3):507-11.

16. Institute of Medicine Committee on Nutritional Status During P, Lactation. Nutrition During Pregnancy: Part I Weight Gain: Part II Nutrient Supplements. Washington (DC): National Academies Press (US)

Copyright (c) 1990 by the National Academy of Sciences.; 1990.

17. Beksac MS, Tanacan A, Hakli DA, Ozyuncu O. Use of the $50 \mathrm{gg}$ glucose challenge test to predict excess delivery weight. International Journal of Gynecology \& Obstetrics. 2018;142(1):61-5.

18. Fadiloglu E, Tanacan A, Unal C, Hakli DA, Beksac MS. Clinical importance of the 75-g glucose tolerance test (GTT) in the prediction of large for gestational age (LGA) fetuses in non-diabetic pregnancies. Journal of perinatal medicine. 2019.

19. Aka N, Sayharman SE, Yaşlak Y, Köse G, Tüfekçi C. Evaluation of perinatal and maternal complications type of deliveries and neonatal outcomes in macrosomic and normal weighed newborns in our clinic between 2000 and 2010 years. Gynecology Obstetrics \& Reproductive Medicine. 2011;17(1):16-9. 